OSTASH B.O. ${ }^{1}$, YUSHCHUK O.S. ${ }^{1}$, KOSHLA O.T. ${ }^{1}$, REBETS Y. ${ }^{4}$, OSTASH I.S. ${ }^{1}$, SEHIN Y.V. ${ }^{1}$, BUSCHE T. ${ }^{2}$, KALINOWSKI J. ${ }^{2}$, MUTH G. ${ }^{3}$, FEDORENKO V.O. ${ }^{1 凶}$

${ }^{1}$ Ivan Franko National University of Lviv,

Ukraine, 79005, Lviv, Hrushevskoho, 4

${ }^{2}$ Center for Biotechnology, Bielefeld University,

Germany, Bielefeld

${ }^{3}$ Interfaculty Institute of Microbiology and Infection Medicine, Tubingen University, Germany

${ }^{4}$ Harvard Medical School,

United States of America, MA 02215, Boston

$凶$ v_fedorenko@franko.lviv.ua, +38(032) 239-44-07, +38(032) 239-44-75

\title{
ELUCIDATION OF THE GENETIC MECHANISMS CONTRIBUTING TO MOENOMYCIN RESISTANCE IN ACTINOBACTERIA
}

Aim. Moenomycins are phosphoglycolipid antibiotics produced almost exclusively by representatives of genus Streptomyces. These antibiotics directly inhibit peptidoglycan glycosyltransferases and are extremely active against cocci. Here we studied how antibiotic-producing actinobacteria protect themselves from toxic action of moenomycins. Methods. Microbiological and molecular genetic approaches were combined to reveal intrinsic levels and distribution of moenomycin resistance across actinobacteria genera, and to pinpoint genes contributing to moenomycin resistance in model strain Streptomyces coelicolor M145. Results. Out of 51 actinobacterial species (90\% of which Streptomyces) being tested, only Streptomyces albus J1074 turned out to be highly susceptible to moenomycin A, although resistant variants can be facilely raised. Several classes of mutations increased level of susceptibility of $S$. coelicolor to moenomycin, although in no case the latter was equal to what we observed in J1074 strain. Conclusions. Moenomycin resistance is widespread across actinobacteria, and it most likely is caused by a combination factors, such as richly decorated cell wall and organization of divisome apparatus. It is possible that moenomycin resistance mechanisms operating in actinobacteria and pathogenic cocci are different.

Keywords: moenomycin, antibiotic resistance, peptidoglycan.

Moenomycin A (MmA; Fig. 1) represents small family of phosphoglycolipid natural products that possess good spectrum of activity and a unique mode of action against bacteria [1]. MmA is not used clinically because of poor pharmacokinetics, which for more than 30 years motivated the search for better tools to manipulate its structure and generate improved analogs. Recently, total synthesis of MmA has been realized [2], and genes for moenomycin biosynthesis (moe) have been cloned, advancing our ability to search chemical space around phosphoglycolipid scaffold. Furthermore, structural details of interaction between moenomycins and their target, peptidoglycan glycosyltransferases (PGTs; or transglycosylases), have been illuminated [3]. Despite the progress in understanding chemistry and biology of moenomycins, it is not known how MmA-producing bacteria avoid its toxic action [4, 5]. Knowledge of such mechanism(s) would help understand and slow down the spread of MmA resistance among pathogens. Little attention to this problem in case of glycopeptide antibiotics has led to dramatic rise of vancomycinresistant bacteria, contributing to a great extent to current crisis in antibiotic therapy [6]. In this work we explored distribution of MmA susceptible and resistant species, as well as morphological and genetic factors that might contribute to the resistance. We show here that a number of factors contribute to MmA resistance in Streptomyces albus $\mathrm{J} 1074$ and S. coelicolor M145, such as spectrum of expressed PGT, divisome $(m r e B)$ and wall teichoic acid genes.

\section{Materials and methods}

Actinobacteria used in this work are stored in the collection of microorganisms-producers of antibiotics at the Department of Genetics and Biotechnology of the University. The studied strains included all known moenomycin producers, model

\footnotetext{
${ }^{\circ}$ OSTASH B.O., YUSHCHUK O.S., KOSHLA O.T., REBETS Y., OSTASH I.S., SEHIN Y.V., BUSCHE T., KALINOWSKI J., MUTH G., FEDORENKO V.O.
} 
strains (S. coelicolor M145, S. lividans 1326, S. albus J1074), representatives of genera Micromonospora, Amycolatopsis, Saccharopolyspora, Actinomadura, Pseudonocardia and Actinoplanes. Full list of strains is available from authors upon request. Escherichia coli strains ET12567 (pUB307) and DH5 $\alpha$ were used for intergeneric conjugations and routine cloning, respectively.

Cosmids used for gene disruption in S. coelicolor M145 (kindly provided by Prof. P. Dyson, University of Swansea, UK) are as follows: K7.1.E06 ( insertion of Tn5062 into sco5039, PGT domain); SCE6.1.G10 (sco2897, PGT domain); h24-2.B01 (sco3901, PGT domain); SCE50.1.H07 (sco2983, similar to TagF, teichoic acid glycosyltransferase); C123.2.F09 (sco2590, similar to TagF, teichoic acid glycosyltransferase); SC4C2.1.B08 (sco7671, homolog of S. grisesus srsA for phenolic lipid synthesis). Expression vectors pKC1139E, pTES and pIJ6902 [7] were used to clone genes as XbaI-EcoRI fragments into respective sites of the vector. All plasmids were verified via sequencing. Sequences of the primers are available from authors upon request. E. coli strains were grown at $37^{\circ} \mathrm{C}$ in LB, $2 \times$ TY or TB for routine applications. Streptomyces strains were grown at $30^{\circ} \mathrm{C}$. Solid oatmeal medium (OM [7]) was used to plate conjugation mixtures. For genomic and plasmid DNA isolation, streptomycetes were grown in TSB for 48-60 h.
Antibiotic resistance was assayed on solid Bennett and MM media; $S$. coelicolor protoplasts were regenerated on solid R2YE as described in [7]. Pure MmA was kindly provided by Prof. D. Kahne (Harvard University).

BLAST search tools (on the server of National Center for Biotechnology Information (NCBI), Bethesda, MD) were used for identify genes of interest in the genomes of Streptomyces. The CDD search engine (BLAST server) and set of programs (HHPred, Pfam, TMHMM, MUSCLE) on the HHSuite toolkit were used (https://toolkit.tuebingen.mpg.de/\#/).

Standard procedures were employed to isolate, construct and analyze recombinant DNA and RNA. E. coli - Streptomyces conjugation and protoplast transformation were done as described [7]. In protoplast regeneration experiments, titer of regenerants on antibiotic-supplemented plates was calculated taking into account the number of unlyzed mycelia (determined plating of protoplasts resuspended in $0.01 \%$ SDS). Primary analysis of antibiotic resistance has been carried out with the disc diffusion method. MmA resistance was also analyzed by the titration of actinomycete spore suspensions on plates containing increasing MmA concentrations. We used commercially available discs or prepared them from fresh antibiotic stocks and Whatman discs ( $\varnothing 5 \mathrm{~mm})$.

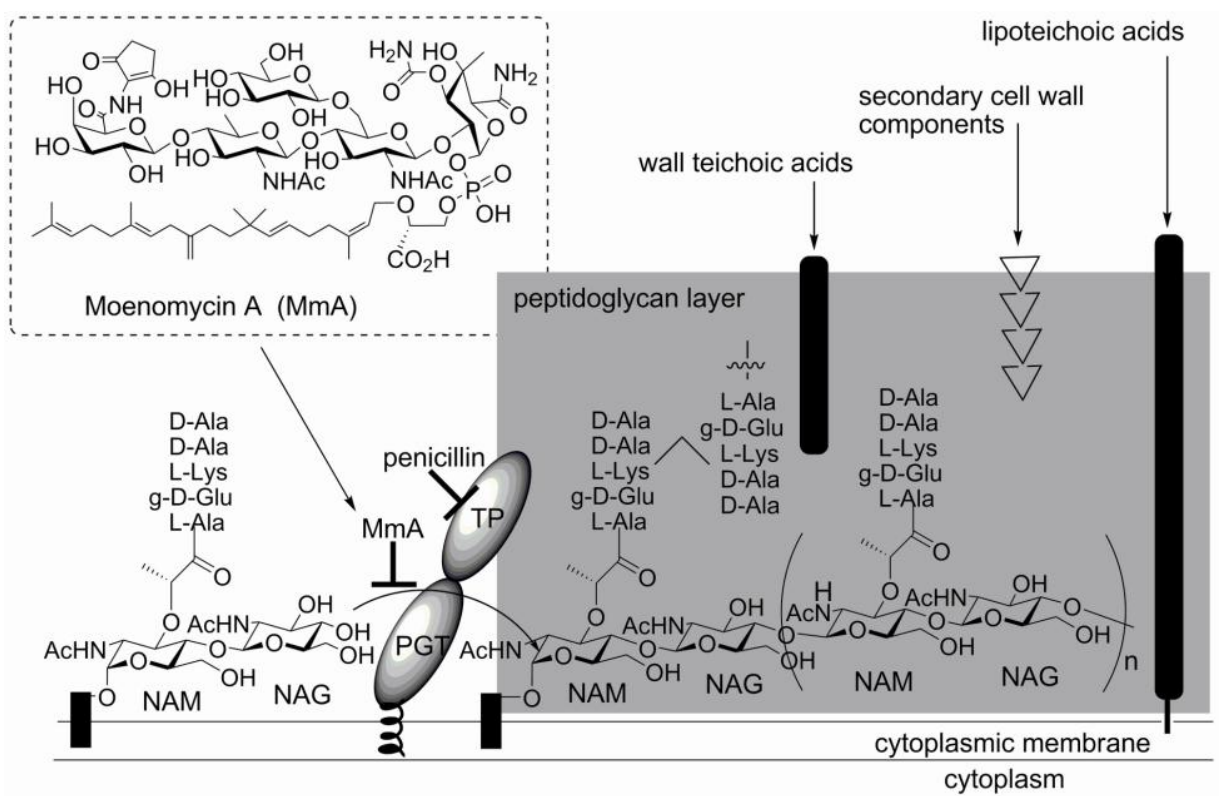

Fig. 1. Moenomycin A (MmA) and extracellular steps of bacterial peptidoglycan biosynthesis. Sites of MmA and penicillin inhibition are indicated. Penicillin binding proteins (PBPs) are shown with both peptidoglycan glycosyltransferase (PGT) and transpeptidase (TP) domains. A part of peptidoglycan layer is shown as a grey shade where other cell wall components (teichoic acids etc) are embedded. Lipid part of Lipid II is shown as black rectangle embedded into cytoplasmic membrane. 
Gene knockouts in S. coelicolor with the help of transposon cosmids were carried out essentially as described in [8]. Three representative $\mathrm{Am}^{\mathrm{r}} \mathrm{Km}^{\mathrm{s}}$ clones for each knockout were used for analysis of the morphology and antibiotic resistance. All mutations were PCR-verified in two rounds. First, the absence of certain wild type gene in the knockout strain has been verified as a failure to amplify it with primers to the ends of the gene. Second, replacement of intact allele with mutated one was checked through a combination of transposonspecific primer (EZR1 or EZL2) and a $s c o$-specific primer (5'- or $3^{\prime}$-terminal). In all cases we observed the expected pattern of PCR bands.

For electron microscopy biomass was grown in TSB for 3 days. The $2 \mathrm{ml}$ sample of the 3-day culture was spun down, washed with water three times and resuspended in a fixative made of $2 \%$ glutaraldehyde in $0.2 \mathrm{M}$ cacodylate buffer at $\mathrm{pH}$ 7.4. The samples were dehydrated with successive solutions containing increasing concentration of ethanol and submitted to the Harvard Medical School Electron Microscopy (EM) Facility for processing.

\section{Results and discussion}

In this work we pursued several research directions. First, it was important to understand whether MmA resistance is characteristic of moenomycin-producing strains, or it is readily present also in MmA nonproducers and non-streptomycete species. Second, using spontaneous MmA resistant $\left(\mathrm{MmA}^{\mathrm{r}}\right)$ variants of $S$. albus, we explored scenarios that might underline the MmA resistance. Besides peptidoglycan, the Grampositive cell wall of Streptomyces is decorated with a number of components (see Fig. 1), which might contribute to MmA resistance. Therefore, in a third topic we focused on analysis of genes for cell wall biogenesis, membrane lipids and cytokinesis as possible MmA resistance targets. Finally, we studied the role of several transporter genes in MmA resistance. Below we describe our results along these four research lines and discuss the most promising future research directions.

MmA resistance is widespread across actinobacteria. We wanted to study MmA resistance in a phylogenetically diverse group, therefore nonStreptomyces strains were included. Second, Streptomyces strains picked for analysis cover all known moenomycin producers as well as one mutant with abolished MmA synthesis and several model strains, whose genomes are available (see Me- thods). The latter will provide a rich genetic background for further studies on MmA resistance. The other streptomycetes were chosen because peculiarities of their growth or susceptibility to other antibiotics that may impact MmA resistance. For example, S. hawaiinesis, S. sioyaensis and S. nogalater are more sensitive to beta-lactams than other Streptomyces, which may impact MmA susceptibility. S. venezuelae exhibits disperse, single-celled mode of growth. S. avermitilis produces no rodlins, small hydrophobic protein that covers aerial hyphae. It was interesting to compare its MmA resistance profile to other strains possessing the rodlet layer. To this end, we revealed that only $S$. albus J1074 exhibited significant susceptibility to MmA. In comparison with MmA producer $S$. ghanaensis or $S$. coelicolor, its survival rate at the lowest and the highest MmA concentrations tested (1 and 100 $\mathrm{mcg} / \mathrm{ml}$ ) dropped more than 4 and 6 orders of magnitude, respectively (Fig. 2). All other actinomycetes were resistant to MmA, showing little or no connection of the studied trait to morphology or phylogeny of the strain.

Spontaneous $\mathrm{MmA}^{\mathrm{r}}$ resistant mutants of $S$. albus J1074: generation and initial studies. After 5 days of growth, $6 \mathrm{MmA}^{\mathrm{r}} S$. albus colonies were observed in a zone of lysis around disc soaked into MmA. After three passages under non-selective conditions, their survival in presence of MmA has been determined. We finally identified a mutant, referred to as $S$. albus R1-100, that stably confirmed its $\mathrm{Mm}^{\mathrm{r}}$ phenotype and showed $44 \pm 3 \%$ survival in presence of $100 \mathrm{mcg} / \mathrm{ml}$ of the antibiotic (compare to $10^{-5} \%$ for J1074, Fig. 2). Its resistance to other antibiotics remained unchanged. There were no differences in growth rate or sporulation of the R1-100 strain in comparison to parent J1074. Using electron microscopy (Fig. 3), we attempted to compare the thickness of cell walls of $S$. albus strains J1074 and R1-100, S. coelicolor and S. ghanaensis. The cell wall thickness was within $0,017-$ $0,026 \mu \mathrm{m}$ range for the studied strains (300 sections were analyzed in each case, an example is shown on Fig. 3). No statistically significant differences in the measured parameter were detected between the strains. We did observe that R1-100 began to produce copiously a yellow pigment, which seems to be produced by $\mathrm{J} 1074$, too, albeit at a much lower level. We note here that production of certain primary and secondary metabolites, such as lipid II and carotenoids could confer bacteria to MmA resistance [3], and this might also be the case for R1100. However, our numerous attempts to find suita- 
ble conditions of extraction and TLC separation of the pigment haven't met with success. Resistance to cell wall-active antibiotics is often modulated by the structure of cell wall polymers other than peptidoglycan, such as teichoic acids. We analyzed the structure of these cell wall polymers in R1-100 and revealed that they are identical to that of J1074 [9], qualitatively and quantitatively.

Cell wall as a $\mathrm{MmA}$ resistance determinant. If the PGTs involved in S. coelicolor M145 cell wall biosynthesis are intrinsically resistant to MmA, then both cells and protoplasts of M145 should display approximately the same level of resistance. The protoplasts of M145 strain have been prepared and regenerated on agar plates in presence of either MmA or penicillin G (100 $\mathrm{mcg} / \mathrm{ml}$ in each case). MmA and penicillin G reduced the protoplast survival to $0.6 \pm 0.4 \%$ and $20 \pm 4 \%$, respectively, as compared to untreated protoplasts $(100 \%$; average protoplasts titer was $6.1 \times 10^{7} \mathrm{ml}^{-1}$ ). Thus, our data point to the fact that cell wall does contribute to $\mathrm{MmA}$ resistance of $S$. coelicolor and, probably, other streptomycetes. Yet, the level of $S$. coelicolor protoplast survival reduction as compared to cells (around 100-fold) is not as dramatic as we observed for S. albus J1074 and R1100 (over 10000-fold). Hence, cell wall composition alone could not explain high level MmA resistance in S. coelicolor.

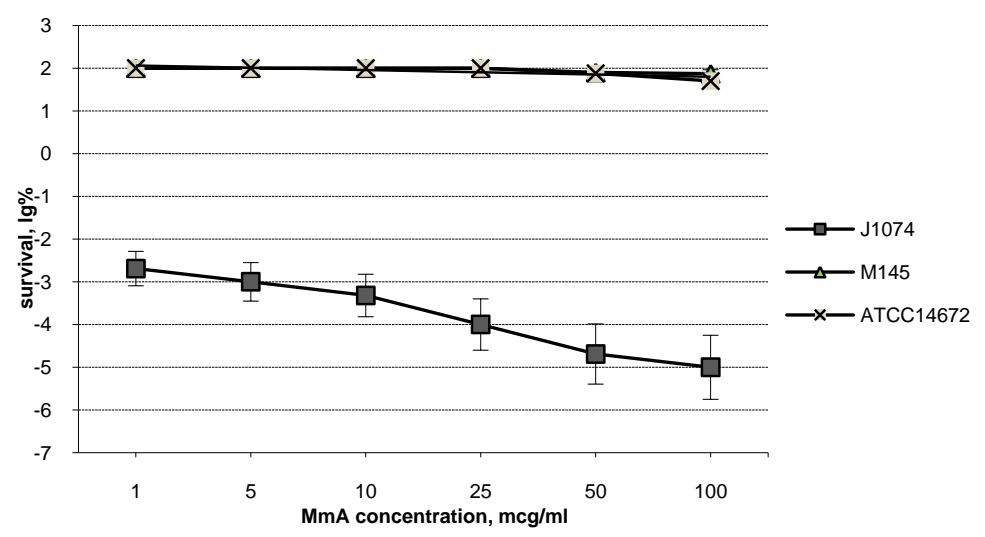

Fig. 2. Survival curves of strains S. coelicolor M145, S. ghanaensis ATCC14672, S. albus J1074 in presence of increasing amounts of MmA.
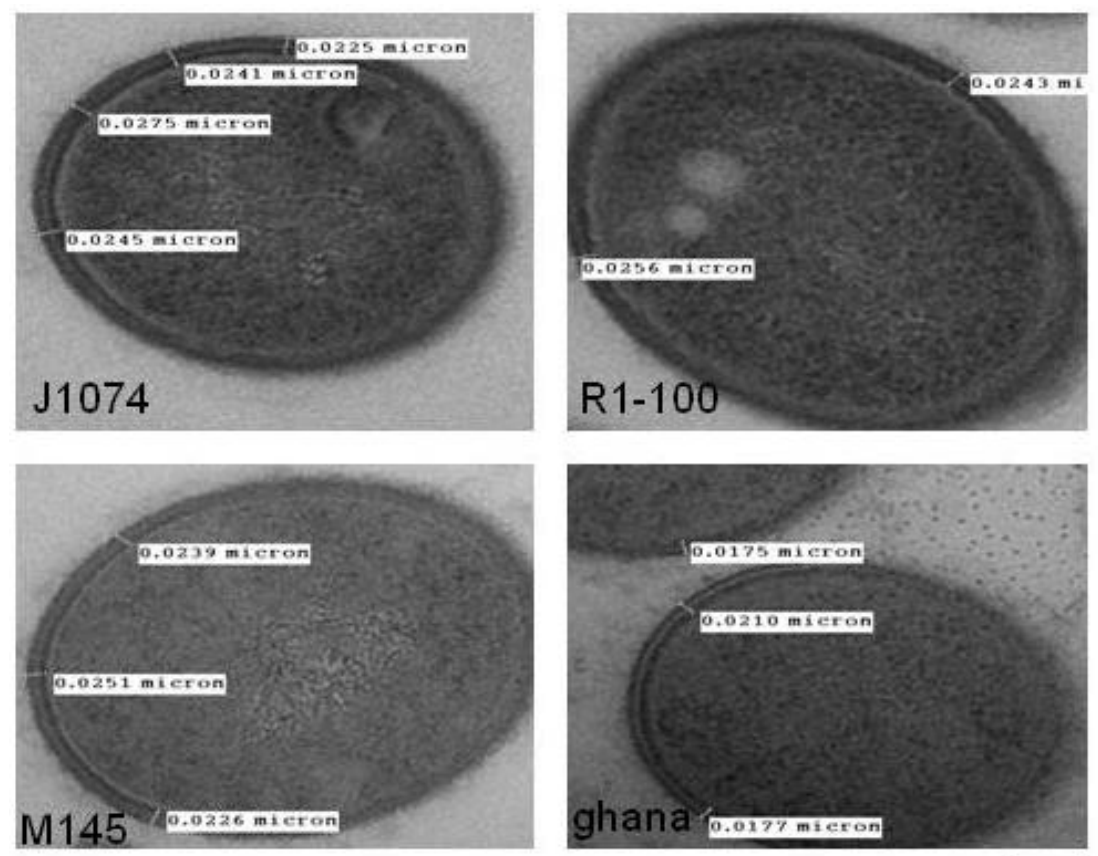

Fig. 3. EM images of hyphal sections of S. albus strains J1074 and R1-100, S. coelicolor M145 (M145) and S. ghanaensis ATCC14672 (ghana). Scale bar under the photos, $100 \mathrm{~nm}$. 
Dissecting the contribution of genes for membrane, cell wall biogenesis and cytokinesis in $\mathrm{MmA}$ resistance. Protoplasts studies suggested that streptomycete PGTs carry no special amino acid substitutions that would relieve their inhibition with MmA.This notion has been further reinforced when we inspected multiple alignment of amino acid sequences of PGTs from $S$. coelicolor and $S$. ghanaensis: no known amino acid substitutions leading to low affinity towards MmA $[10,11]$ can be observed in PGTs of aforementioned species. $S$. albus PGTs are almost identical to other PGTs being compared, and the observed variability is common to MmA-sensitive PGTs from E. coli or cocci. Hence, MmA resistance of $S$. coelicolor and $S$. ghanaensis is not likely to result from low-affinity PGTs. Recently RodA enzymes in Bacillus and Escherichia were shown to possess PGT activity that is unsusceptible to MmA [12]. We identified RodA orthologs in S. coelicolor M145 (Sco2607) and S. albus J1074 (Xnr4338). Through analysis of our own and publicly available transcriptomes, we found no differences in rodA expression in S. coelicolor and S. albus.

Next we profiled MmA resistance in a set of $S$. coelicolor strains deficient in one of the genes involved in cell wall biogenesis, membrane lipids production and division. First, we generated, using transposon cosmids, a set of $S$. coelicolor mutants deficient in genes for peptidoglycan (PGT genes

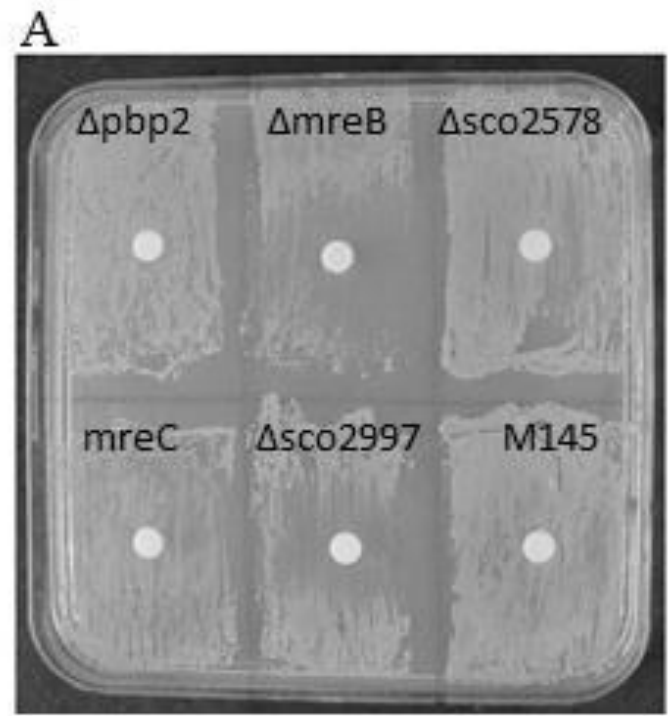

sco2897, sco3901, sco5039), teichoic acids (sco2590, sco2983) and putative phenolic lipids (sco7671) biosynthesis. All generated mutants did not differ from the parent strain in growth rate or sporulation. In terms of antibiotic resistance, sco3901 mutant was more susceptible to $\mathrm{MmA}$ $(20 \pm 3 \%$ survival rate at $100 \mathrm{mcg} / \mathrm{ml}$ of antibiotic compared to $87 \pm 5 \%$ for wild type) and sco 7671 mutant was 25 times less resistant to penicillin $\mathrm{G}$ at $100 \mathrm{mcg} / \mathrm{ml}(4 \pm 1 \%$ vs $97 \pm 5 \%)$. We also overexpressed PGT genes in $S$. coelicolor in hope that increased quantities of MmA target proteins might lead to increases in MmA susceptibility; however no changes in antibiotic resistance have been detected (data not shown). Finally, we examined following $S$. coelicolor strains disrupted in cell wall biosynthesis ( $p b p 2$, sco2997 (tagF-like), sco2578 (tagV-like)) and cytokinesis (mreB, mreC) genes described by us in previous works [13]. As compared to M145, mreB, mreC and sco2997 mutants were more susceptible to MmA after $48 \mathrm{~h}$ of growth in presence of antibiotic disc, however later on (72 h) halo of growth inhibition disappeared (Fig. 4). In all, it appears that impairment of cell wall structure facilitates the access of MmA to PGTs; however, none of these mutations lead to a level of MmA susceptibility observed for $S$. albus. Therefore, asyet-unstudied MmA-resistant PGTs operate in Streptomyces.

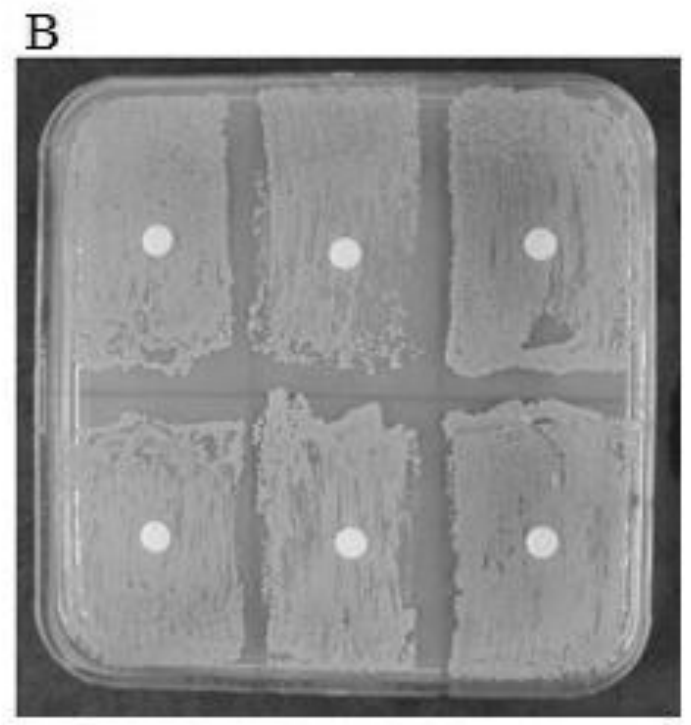

Fig. 4. MmA resistance among selected S. coelicolor mutants after 48 (A) and 72 (B) h of growth on TSA. $10^{7}$ spores were seeded to obtain patches of lawns where discs impregnated with $50 \mathrm{mcg}$ of MmA were stacked upon. 


\section{Transporter genes in moenomycin} resistance. Export of peptidoglycan precursor Lipid II (see Fig. 1) requires dedicated transporter proteins [14]. Such transporters may also be involved in active extrusion of MmA [3]. We identified, in silico, two presumable Lipid II flippases in S. ghanaensis genome, SSFG_03627 and $S S F G \_01411$, and introduced them (on $\phi C 31$ based integrative vector pTES) into S. albus J1074. As control cases, we introduced into J1074 two transporter genes from landomycin A producer $S$. cyanogenus S136: lanJ (plasmid pOOB104a) and lanJ paralog scy3375 (pMO38a). Two latter genes are not related to export of lipid-linked polysaccharide, and increased MmA resistance of pOOB104a- or pMO38a-borne J1074 would be construed as a result of nonspecific MmA export. None of the generated strains had distinct MmA resistance profile.

\section{Conclusions}

MmA resistance is widespread in actinobacteria, and is not caused by the intrinsic low affinity of typical PGTs towards the antibiotic. Chemical composition of streptomycete cell wall, particularly presence of teichoic acids, contributes to the high level MmA resistance, although cell wall itself is not a key resistance determinant. Clearly, cell wall lesions create temporary perforations allowing PGT targeting by MmA. Principal mechanism of MmA resistance in Streptomyces remains elusive. It is important to undertake broader study of RodA homologs in actinobacteria and to carry out deeper physiological and genomic analysis of $S$. albus R1100 strain.

\section{References}

1. Ostash B., Walker S. Bacterial transglycosylase inhibitors. Curr. Opin. Chem. Biol. 2005. Vol. 9. P. 459-466. doi: 10.1016/j.cbpa.2005.08.014.

2. Taylor J.G., Chen X., Kahne D.. The total synthesis of moenomycin A. J. Am. Chem. Soc. 2006. 128. P. 15084-15085. doi: 10.1021/ja065907x.

3. Ostash B., Walker S. Moenomycin family antibiotics: chemical synthesis, biosynthesis, and biological activity. Nat. Prod. Rep. 2010. Vol. 27. P. 1594-1617. doi: 10.1039/c001461n.

4. Ostash B., Doud E., Fedorenko V. The molecular biology of moenomycins: towards novel antibiotics based on inhibition of bacterial peptidoglycan glycosyltransferases. Biol. Chem. 2010. Vol. 391. P. 499-504. doi: 10.1515/BC.2010.053.

5. Wright G.D. Antibiotic resistance in the environment: a link to the clinic? Curr. Opin. Microbiol. 2010. Vol. 13. P. $589-594$. doi: 10.1016/j.mib.2010.08.005.

6. Klare I., Mascher J. Occurrence and spread of antibiotic resistances in Enterococcus faecium. Int. J. Food Microbiol. 2003.88. P. 269-290. doi: 10.1016/S0168-1605(03)00190-9.

7. Kieser T., Bibb M.J., Buttner M.J., Hopwood D.A. Practical Streptomyces Genetics. The John Innes Foundation, Norwich, (UK), 2000. $630 \mathrm{p}$.

8. Bishop A., Dyson P. Systematic insertional mutagenesis of a streptomycete genome: a link between osmoadaptation and antibiotic production. Genome Res. 2004. V. 14. P. 893-900. doi: 10.1101/gr.1710304.

9. Shashkov A.S., Ostash B.O., Fedorenko V. Cell wall glycopolymers of Streptomyces albus, Streptomyces albidoflavus and Streptomyces pathocidini. Antonie Van Leeuw. 2016. Vol. 109. P. 923-936. doi: 10.1007/s10482-016-0691-8.

10. Barrett D., Yanqiu Y., Walker S. Analysis of glycan polymers produced by peptidoglycan glycosyltransferases. J. Biol. Chem. 2007. Vol. 282. P. 31964-31971. doi: 10.1074/jbc.M705440200.

11. Rebets Y., Lupoli T., Schiener K., Kahne D., Walker S. Moenomycin resistance mutations in Staphylococcus aureus reduce peptidoglycan chain length and cause aberrant cell division. ACS Chem Biol. 2014. Vol. 9. P. 459-467. doi: $10.1021 / \mathrm{cb} 4006744$

12. Meeske A.J., Mekalanos J., Walker S., Kahne D., Rudner D. SEDS proteins are a widespread family of bacterial cell wall polymerases. Nature. 2016. Vol. 537. P. 634-638. doi: 10.1038/nature19331.

13. Ladwig N., Wohlleben W., Muth G. Control of morphological differentiation of Streptomyces coelicolor A3(2) by phosphorylation of MreC and PBP2. PLoS One. 2015. Vol. 10. P. e0125425. doi: 10.1371/journal.pone.0125425.

14. Ruiz N. Lipid flippases for bacterial peptidoglycan biosynthesis. Lipid Insights. 2016. Vol. 8. P. 21-31. doi: 10.4137/LPI.S31783. 
ОСТАШ Б.О. ${ }^{1}$, ЮЩУК О.С. ${ }^{1}$, КОШЛА О.Т. ${ }^{1}$, РЕБЕЦЬ Ю.В. ${ }^{4}$, ОСТАШ I.C. ${ }^{1}$, СЕГІН Ю.В. ${ }^{1}$, БУШЕ Т. ${ }^{2}$, КАЛІНОВСКІ Й. ${ }^{2}$, МЮТ Г. ${ }^{3}$, ФЕДОРЕНКО В.О. ${ }^{1}$

${ }^{1}$ Львівський начіональний університет ім. І. Франка,

Україна, 79005, м. Львів, вул. Грушевського, 4

${ }^{2}$ Центр Біотехнології, університет Білефельда,

ФР, Білефельд

${ }^{3}$ Інститут мікробіології та медицини, Тюбінгенський університет,

$\Phi P H$

${ }^{4}$ Гарвардська медична школа,

США, МА 02215, Бостон

\section{ВИВЧЕННЯ ГЕНЕТИЧНИХ МЕХАНІЗМІВ СТІЙКОСТІ ДО МОЕНОМІЦИНУ В АКТИНОБАКТЕРІЙ}

Mema. Дослідити генетичні механізми стійкості до моеноміцину А (МмА) в актинобактерій. Методи. Використано мікробіологічні та молекулярно-генетичні підходи, та модельні штами Streptomyces coelicolor M145 й S. albus J1074 для виявлення поширення досліджуваної ознаки, а також роль компонентів клітинної стінки на рівень резистентності. Результати. Серед 51 дослідженого штаму актинобактерій виявлено, що тільки S. albus J1074 високочутливий до МмА. Отримано мутанти J1074 стійкі до МмА. Рівень стійкості останніх не визначається потовщенням клітинної стінки. Один із $\mathrm{Mm}^{\mathrm{r}}$ мутантів характеризується підвищеною продукцією наразі неідентифікованих забарвлених метаболітів. Хімічний склад клітинної стінки впливає на рівень стійкості до МмА, але не $\epsilon$ визначальним фактором. Пошкодження синтезу тейхоєвих кислот мало найбільший вплив на рівень стійкості до МмА; другий за величиною вплив мали гени дивізомного комплексу $($ mreB). Висновки. Стійкість до МмА в стрептоміцетів визначається поєднанням особливостей хімічного складу клітинної стінки та, імовірно, експресії наразі невиявлених низькоафінних до МмА пептидогліканових глікозилтрансфераз, на кшталт RodA.

Ключові слова: моеноміцин, стійкість до антибіотиків, пептидоглікан. 